\title{
Curious little book on rabies
}

Rabies: The Facts. Edited by Colin Kaplan. Pp. 116. (Oxford University: Oxford and London; Corgi: London, 1977.) Hardback (OUP) $£ 1.95$ paperback (Corgi) 75 pence.

THIS is a curious little book on rabies. If it is intended for a scientific audience, it is the first such book I know of without references. If it is a book for the general public, it contains highly specialised information on nucleoproteins, structural proteins of the virus, and comments rather advanced for the average reader such as: "In their model of rabies virus, Vernon and his colleagues have depicted the larger of the two $M$ proteins $\left(M_{1}\right)$ as being adjacent to the ribonucleoprotein".

The book is divided into seven chapters, begining with a discussion of the world problem, and emphasising the under-reporting of the disease. Under-reporting has also been discussed in a notable 1967 report by Sanmartín et al. (Sanmartín, Correa, Dueñas \& Muñoz, Memorias del Primer Seminario Nacional Sobre Rabia, Medellín, Colombia, 155-161, 1967) in which $1.7 \%$ of 1,596 autopsies in the University Hospital in Cali, Colombia, showed that death was due to rabies.

It is unfortunate that no maps or tables are included in a discussion of world rabies epidemiology, and that the description of the flourescent antibody technique is not accompanied by a diagram making it a little more intelligible for the layman. The technique has been of tremendous value in rabies diagnosis and investigations.

The descriptions of the disease attests to the terror that rabid dogs once instilled in the hearts of English countrymen, much as it does today in thousands of people in most developing countries. It has often been noted that rabies infection in the field frequently results in antibody production in a sizeable percentage of animals, much as described in this book. This includes animals such as insectivorous bats (Burns \& Farinacci J. Infect. Dis. 97, 211; 1955), mongooses (Everard, Baer \& James J. Wildlife Dis. 10, 190; 1974), dogs (Doege \& Northrop Lancet, ii, 826;
1974) and other fairly resistant species. Much is made of the two human recoveries from rabies (Hattwick et al. Ann. Intern. Med. 76, 931; 1972; Porras et al. Ann. Intern. Med. 85, $44 ; 1976)$, as well as one purported carrier dog (Veeraraghavan et al., Ann. Rep. Pasteur Institute of Southern India, 66, 1968), yet it has not been pointed out that these are bizarre exceptions to the rule.

The chapter on rabies virus itself by Crick and Brown is a complete description of the morphology, chemistry and structural subunits of the virus, and of rabies-related viruses. It also covers replication of the virus, synthesis of virus components and other products from infected cells.

The chapter on human rabies includes various aspects of the disease in man, including susceptibility, symptomatology, diagnosis and prevention. An amazing anecdotal series of cases of rabies transmitted from man to man is succeeded by a statement that ". . . there is no completely documented case of man transmitting rabies to man", in which case it seems pointless to even mention the dramatic anecdotal cases. Another amazing statement is: "For reasons which are unknown rabies is up to seven times commoner in men than in women: this also applies to animals". This statement may be applicable to man (see review by Hattwick in The Natural History of Rabies, Academic, New York, 1975), but it is certainly not for animals. Verts (The Biology of the Striped Skunk, University of Illinois Press, Urbana, Chicago and London, 1967) writes that "Of the 20 rabid striped skunks caught in northwestern Illinois, 19 (95.0 per cent) were females". This type of information should not be included unless it is properly documented.

The chapter on rabies in animals includes a table listing incubation periods for various species, with errors: for example, incubation periods of more than 5 months have been reported for foxes (Sikes, Am. J. vet. Res. 23, 1041; 1962) and periods of more than one year have been reported in cattle (Abelseth \& Lawson, cited by Bell, The Natural History of Rabies,
Academic, New York, 1975). Photographs of humans and animals with rabies, as well as electron micrographs of rabies virus are included in this chapter. There is rightful emphasis on the variability of the signs in dogs, and on the fact that relatively few develop furious rabies. It is again unfortunate that no references are included; for example, I am not acquainted with the outbreak of rabies reported in pigs. Other curious statements such as "Deer are as prone to rabies as cattle ..." should be documented. The chapter ends with the astounding suggestion that "There is a potential danger here (that is, Britain) that rabies might enter this country and become enzootic in mink much the same way it has become established in the mongoose..." One wonders why this has not alneady occured in the numerous countries where rabies is enzootic and mink are plentiful.

The next two chapters are on fox behavioural ecology and the prospects of wildlife rabies in Britain. They include a description of fox behaviour and rabies in the fox, with summaries of studies done in Britain and other countries. These chapters are basically well presented and include much useful information. The possible transmission of rabies from cats to foxes is emphasised, without any explanation as to why this mode of transmission is believed to occur. In fact, Wachendörfer has shown (Dt. tierärztl. Wschr. 69,$555 ; 1962$ ) that the case of rabies transmitted from foxes to cats are closely related and the two epizootiological curves can be virtually superimposed.

The short chapter on rabies vaccines by Turner encompasses most of what is known today about human and veterinary vaccines, with emphasis on the difference between pre-exposure vaccination (such as vaccination of animals and of people at risk to exposure in the laboratory), and postexposure vaccination.

George M. Baer is Chief of the Viral Zoonoses Branch of the Center for Disease Control (Lawrenceville Facility), Lawrenceville, Georgia. 